Originalni naučni rad

Primljen: 11. 11. 2017.

Revidirana verzija: 18. 11. 2017.

UDK: 343.85:343.91-053.5/.6(497)

Prihvaćen: 30. 1. 2018.

doi:10.5937/nabepo22-15662

\title{
UTILIZING THE CAPACITY OF POSITIVE PEER PRESSURE THROUGH THE GLOBAL YOUTH JUSTICE MOVEMENT: A 'GOLDEN' OPPORTUNITY FOR THE BALKANS ${ }^{1}$
}

\author{
John Winterdyk ${ }^{2}$ \\ Department of Economics, Justice, and Policy Studies \\ Mount Royal University, Calgary, Alberta, Canada
}

\begin{abstract}
The predicament of juvenile delinquency for most nations, including that of the Balkan region at large, has been something of an enigma ever since juvenile justice legislation was first introduced. In recent years, juvenile delinquency in the Balkans has not only been increasing but its gravity has also trended upward and added to the burden of a strained juvenile justice system. This article presents an alternative option to the formal juvenile justice system which is designed to empower youth, which builds community capacity and youth resiliency, and is reintegrative and restorative in nature. An overview of the peer court model is presented and described within a possible Balkan context. Various evidence is discussed as to its relative success in other regions of the world. The paper concludes with several observations as to why the peer court model could/should be adopted
\end{abstract}

\footnotetext{
1 The author would like to acknowledge the input and feedback of Mr. Scott B. Peterson, the founder and CEO of the Global Youth Justice movement. Parts of this article appear in a shorter article titled The Global Youth Justice Movement: Harnessing the Power of Positive Peer Pressure by J. Winterdyk and S. Peterson (2017). The Global Youth Justice Movement: Harnessing the Power of Positive Peer Pressure, Justice Report/Actualités Justice, 32(3): 9-12.

2 Full Professor, jwinterdyk@mtroyal.ca
} 
by the countries in the Balkans along with several pragmatic and practical considerations around the implementation and administration of the model.

Keywords: juvenile delinquency, peer courts, alternative measures, diversion, restorative justice.

\section{Introduction}

Juvenile delinquency has represented something of an enigma to criminal justice systems around the world. ${ }^{3}$ Despite the plethora of initiatives and resources directed towards combatting the plight of juvenile delinquency and the voluminous body of related research, the plight of juvenile crime/delinquency continues to be the bane of most jurisdictions. ${ }^{4}$ The Balkan region is no exception. ${ }^{5}$

According to several recent studies on juvenile delinquency in the Balkans, the region has been struggling with both rising and persistent delinquent activity, ${ }^{6}$ even though the rates generally remain lower than in most European Union (EU) countries. The increase in violent youthful offenders entering the justice system is taxing the time and limited service resources of many of the Balkan countries as they generally lack the resources, capacity, and/or political will to introduce prevention and/or rehabilitation programs. ${ }^{7}$ For example, although Bosnia and Herzegovina drafted new juvenile justice law in 2011 to address its' primarily punitive approach, the legislation has not been acted

\footnotetext{
3 See: Winterdyk, J. \& Smandych, R. (eds.). (2016). Youth at risk and youth justice (3 ${ }^{\text {rd }}$ ed.). Toronto, ON: Oxford University Press

4 See, for example: Winterdyk, J. (ed.). (2015). Juvenile Justice: International perspectives, models, and trends. Boca Raton, FL.: CRC Press

5 See: Getos Kalac, A-M., \& Bezic, R. (2017). Criminology, crime and criminal justice. European J. of Criminology, 14(2): 242-266; Bezic, R. (2017). Juvenile delinquency in the Balkans. Cardiff, Wales: $17^{\text {th }}$ Annual European Society of Criminology conference

6 E.g.: Bezic, R. (2017). Juvenile delinquency in the Balkans. Cardiff, Wales: $17^{\text {th }}$ Annual European Society of Criminology conference; Buric, A. (2011). Youth crime law stalls in Bosnia. Retrieved from http://www.balkaninsight.com/en/blog/youth-crime-law-stallsin-bosnia; Buric, A. (2011). Rehabilitating Hungary's young offenders. Retrieved from http://www.balkaninsight.com/en/blog/rehabilitating-hungary-s-young-offenders 7 See generally: Derencinovic, D., \& Getos, A-M. (2009). Uvod u kriminologiju s osnovama kaznenog prava. Zagreb. Pravni fakultet Sveucilista u Zagrebu; Kilchling, M. (2016). Violence in the Balkans in the focus of Balkan Criminology's current research activities. 3rd Annual Conference of the Max Planck Partner Group for Balkan Criminology "Violence in the Balkans". Faculty of Law, University of Bucharest/Romania; Marsavelski, A. (2012). Alternatives to custody for young offenders: National report on juvenile justice trends: Croatia. Brussels, Belgium: European Union Project. Retrieved from http://www.oijj.org/sites/ default/files/baaf_croatia1.pdf
} 
upon by the government. ${ }^{8}$ And while examples of 'hope' can be found, they do not represent the norm among any of the Balkan countries. ${ }^{9}$ Unfortunately, the picture is not much brighter in most of the other Balkan countries. However, as has been constructively demonstrated in other parts of Europe and internationally, an evidence-informed case can be made for the countries in the Balkan region to explore alternatives to its current conservative and mostly punitive approaches to dealing with juvenile offenders. ${ }^{10}$

To afford greater attention to the plight of juvenile offenders, it is necessary for policy-makers and governments not only to become better informed about what works and doesn't work, but then to realize and actualize the need to reallocate the resources that are allocated to the containment of juvenile crime. ${ }^{11}$ As has been well documented, there is ample evidence to show that regardless of where one lives in the world, most juvenile offenders do not commit crimes by (rational) choice but through necessity and/or their behaviour is the result, or by-product of the environment they grow up in. ${ }^{12}$ Within a traditional criminological context, juvenile delinquency can be explained because of 'social disorganization', 'strain', 'differential association', or as Bezic ${ }^{13}$ and several others affiliated with the MMPG group and the ISRD3 survey project have suggested, delinquency in the countries surveyed is related to such social control factors as social disorganization and poor school attachment.

In sum, it can be said that most delinquency is the result of failed opportunity and a lack of social (informal and formal) controls for youth in the Balkans. The Bulgarian scholar Ivan Krastev ${ }^{14}$ said it perhaps most directly when he wrote: "The Balkans today still appear to be an explosive mixture of weak states, non-states, and present or future protectorates. In reports to policy

8 Buric, A. (2011). Youth crime law stalls in Bosnia. Retrieved from http://www.balkaninsight.com/en/blog/youth-crime-law-stalls-in-bosnia; Buric, A. (2011). Federation fails to curb rising Bosnian youth crime. Retrieved from http://www.balkaninsight.com/en/article/federation-fails-to-curb-rising-bosnian-youth-crime

9 For an exception, see: Buric, A. (2011). Rehabilitating Hungary's young offenders. Retrieved from http://www.balkaninsight.com/en/blog/rehabilitating-hungary-s-young-offenders; Buric, A. (2011). Federation fails to curb rising Bosnian youth crime. Retrieved from http://www.balkaninsight.com/en/article/federation-fails-to-curb-rising-bosnianyouth-crime

10 See: Winterdyk, J. (ed.). (2015). Juvenile Justice: International perspectives, models, and trends. Boca Raton, FL.: CRC Press

11 See generally: Waller, I. (2013). Smarter crime control. New York, NY: Rowman \& Littlefield

12 See, e.g. Oudshoorn. J. (2015). Trauma-informed youth justice in Canada. Toronto: CSPI

13 Bezic, R. (2017). Juvenile delinquency in the Balkans. Cardiff, Wales: $17^{\text {th }}$ Annual European Society of Criminology conference

14 Krastav, I. (2002). Democracy without choice. Journal of Democracy, 13(3): 39-53.Retrieved from http://commonweb.unifr.ch/artsdean/pub/gestens/f/as/ files/4760/25735_093221.pdf 
makers, the region is described as a place where borders (when defined) are soft, identities are hard, reform policies have failed, and the future is cloudy."

While in countries like India ${ }^{15}$ and China where their respective populations continue to grow, ${ }^{16}$ the population in the Balkan States is expected to continue to decline by as much as $15 \%$ by $2050 .{ }^{17} \mathrm{~A}$ decline in population is usually analogous to social and economic hardship which in addition to limiting the resources necessary to combat juvenile crime, the limited number of opportunities are likely to add to 'anomie', frustration/strain, 'social disorganization', and create a fertile environment for delinquent activity.

In the wake of available data showing that the rate of juvenile crime in the Balkans is not only growing but that there has been a simultaneous increase in the level of violent crime committed by young persons, there would appear to be a clear need to examine the issue and trend not only at a state level but also at a regional level. As an outsider, this author can only assume that this is causing concern among criminal justice professionals, policy-makers, and community leaders alike. ${ }^{18}$ Coupled with the current growth in the nation's juvenile age population, there is a very real risk (without trying to sound like an alarmist) that the trend will continue unless there is a concerted shift in how juvenile crime is addressed collectively and individually throughout the Balkan region.

Admittedly, as the esteemed American sociologist Edwin Sutherland observed back in 1934, (juvenile) crime statistics can often be skewed and/or because much of this criminal activity is committed by groups and often goes undetected (i.e. 'dark figure' of crime). ${ }^{19}$ Nevertheless, there is a clear and growing propensity for criminal activity by juveniles which demands the attention and direct response of policy leaders from all levels of government throughout the Balkan region, and dedicated research by academics and researchers such as those at the Max Planck Partnership Group based in Zagreb. Fortunately, by looking outside of the country (i.e. comparative criminology and/or criminal justice) at what is being done in some other jurisdictions may prove helpful in informing and guiding the formulation of bold policy decisions that will

15 See: Dash, P.K. (2013). By 2017, India's slum population will rise to 104 million. The Times of India. Retrieved from https://timesofindia.indiatimes.com/india/By-2017-Indias-slum-population-will-rise-to-104-million/articleshow/21927474.cms

16 See: http://www.worldometers.info/world-population/china-population/

17 Zivanovic, M. (2017). Balkan states face big population drops, UN warns. Balkan Insight. Retrieved from http://www.balkaninsight.com/en/article/populations-plunging-in-most-balkans-countries-report-06-22-2017

18 See: Getos Kalac, A-M. \& Bezic, R. (2017). Criminology, crime and criminal justice. European J. of Criminology, 14(2): 242-266.

19 See: Winterdyk, J. \& Smandych, R. (eds.). (2016). Youth at risk and youth justice (3 $3^{\text {rd }}$ ed.). Toronto, ON: Oxford University Press 
strategically direct resources to support innovative programming where it can be most effective.

Another issue that confronts the Balkans, and many other jurisdictions, is the fact that legislatures are responding to the increased societal demand for a wider variety of juvenile offenders to experience more punitively-oriented judicial sanctioning (as opposed to the primarily rehabilitative approaches practiced in recent years) by enacting laws that provide for such and which curtail police discretion at arrest. ${ }^{20}$ And although it was not possible to locate many comprehensive studies on juvenile justice systems in the Balkans, it is generally acknowledged that the legacy of the 1990 war, post-Soviet influence, and prevailing cultural values throughout the region that in the absence of increased resources for police, the courts, and formal response mechanisms, these tactics further increase the caseloads of the courts, and burden the juvenile justice system in general. ${ }^{21}$ Thus, the "systemic neglect" is perpetuated by legislation which is largely ineffectual and inefficient. Such factors are further compounded by the continual eroding of public faith and support in the system. This concern is reflected by several studies which showed that despite all its promises to hold perpetrators of the former Yugoslavian war accountable, the ICTY failed to deliver and further eroded public opinion about the criminal justice system. ${ }^{22}$ Similarly, The Balkan Barometer report of 2015, which was based on public opinion showed that while there were (to be expected) some variations between the countries, that "overall satisfaction with the rule of law, the effectiveness, and the impartiality of the governance structures is rather low". 23

With this brief overview on the state of juvenile justice and the juvenile justice system in most, if not all the Balkan countries, there is a need among all (at least most) juvenile justice systems to provide alternative sentencing and response options/models which sanction the juvenile offender while allowing for that young person to be held accountable in a positive manner to themselves and the community for their delinquent and criminal behavior.

The balance of this article explores a promising new option to formal sanctions that have proven to be cost efficient and cost effective. And although it is based on the established principles of diversion and restorative justice, it is a

20 See e.g.: Vojta, F. (2015). Imprisonment in the Balkans: Some remarks on the life and long-term imprisonment in countries of former Yugoslavia. Balkan Criminology New. 1, p. 1-5.; Vujovic, S. (2015). International Self Report Delinquency Study (ISDR-3) in Bosnia and Herzegovina. Balkan Criminology New, 1, p. 8-9.

21 See e.g.: Ginio, E. (2016). The Ottoman culture of defeat. United Kingdom: C. Hurst \& Co. 22 See: Klarin, M. (2009). The Impact of the ICTY Trials on Public Opinion in the Former Yugoslavia. Journal of International Criminal Justice, 7(1), p. 89-96.

23 Balkan Barometer 2015. Public Opinion Survey (2015). Regional Cooperation Council Secretariat (RCC), p. 92. Retrieved from http://www.rcc.int/seeds/files/RCC_BalkanBarometer2015_PublicOpinion_FIN_forWeb.pdf 
model that is quickly gathering support around the world and may prove to be of value to the Balkan countries. Therefore, in addition to providing an overview of the peer court model, this article attempts to place the model within the context of Balkan's juvenile justice system.

\section{A viable option to conventional juvenile justice practices}

What began as a 'Global Goal' by the American Social Entrepreneur Scott Peterson in 1993, peer court volunteer-driven youth justice diversion programs, also referred to as youth/teen/student court and peer jury, have mushroomed from 78 programs in 1994 to over 1,700 communities around the world on four continents (i.e. North America, Europe, Africa, and Asia) as of 2017, with no signs of this local volunteer-driven approach to Youth Justice and Juvenile Justice slowing down anytime soon. In the USA, volunteer-driven peer court diversion programs can now be found in forty-nine states, the District of Columbia, and dozens of Native American and Alaskan Native Tribes. Continuous research and ongoing evaluations are not only adding to the growing momentum, but the evidence is also demonstrating reduced recidivism rates, high social returns on investment, fostering of prosocial attitudes, and active civic involvement among both youth volunteers, and youthful offenders. ${ }^{24}$ Yet, there is no such formalized program in any of the Balkan countries.

This article will provide an overview of peer court diversion programs, describe how they could readily become a diversion program in any of the Balkan countries regardless of whether they are the EU members or not and regardless of any prevail resources challenges. However, what will need to be determined is whether the respective countries have provisions in their legislation to accommodate the option of diversion or alternative measures whose objectives include provisions aimed at avoiding the use of criminal proceedings. Fortunately, there is evidence that such provisions do exist in some, if not most of the countries in the region. ${ }^{25}$ This is in part because the countries have all signed the United Nations Convention on the Rights of the Child (CRC) which includes standards for the use of alternative measures. However, as Marsavel-

24 Peterson, S.B. (2017). Teen, peer youth court. Retrieved from http://www.globalyouthjustice.org/Training_and_Events.html

25 See: Sijerčić-Čolić, H. (n.d.). Juvenile justice as a key element of national human rights policy and restorative juvenile justice - recent trends in juvenile delinquency and juvenile justice in Bosnia and Herzegovina. Retrieved from https://www.unicef.org/tdad/5hajrijasijercic.pdf; Marsavelski, A. (2012). Alternatives to custody for young offenders: National report on juvenile justice trends: Croatia. Brussels, Belgium: European Union Project. Retrieved from http://www.oijj.org/sites/default/files/baaf_croatia1.pdf

[6] NBP • Žurnal za kriminalistiku i pravo 
ski ${ }^{26}$ notes in his report on the juvenile justice system in Croatia the standard although available is not well utilized. A report by UNICEF on the juvenile justice in Serbia made a similar observation. The report stated that "most diversionary solutions (in Serbia) lack the necessary resources and back-up services. There are questions over which branch of government is responsible..."27 Therefore, given it can be assumed that most, if not all, of the countries in the region are experiencing similar challenges and that there needs to be a more concerted effort placed on ensuring young persons and youth-at-risk have options that aim to support and help young persons' transition safely through their adolescent years.

In general terms, the model advocates a degree of informality when dealing with young offenders, or "child in conflict with law" as used in some other jurisdictions, ${ }^{28}$ and creating individualized treatment based on the needs and personal situation of the young person. In addition, as is the case in several Anglo-speaking countries (e.g. the United Kingdom, New Zealand, Australia, Canada, and the United States), their respective youth justice legislation includes provisions that allow, or call for the use of alternative predisposition towards the handling and processing of juveniles in conflict with law and follows a policy which is non-punitive and reformative in nature. However, as signatory members of the CRC and with most Balkan states having some provision in their respective juvenile justice legislation, they would appear to be sufficiently well situated to consider exploring the pre-charge diversion option which has become well established in the United States and Canada, and is spreading quickly to many foreign jurisdictions.

Furthermore, borrowing from the Canadian system, the pre-charge diversion option being proposed falls under what is referred to as an 'extrajudicial measure' (EJM) (i.e. "outside the court"). ${ }^{29}$ Under this provision (i.e. Section 4 of the Youth Criminal Justice Act of Canada) the police are expected to consider using this option when dealing with youth who have committed minor offences - again, since all the Balkan countries are signatory members of the $\mathrm{CRC}$, most of the respective country legislation include some type of provision for the use of alternative measures and/or at least allow for the consideration of accommodation for pre-diversions options.

26 Marsavelski, A. (2012). Alternatives to custody for young offenders: National report on juvenile justice trends: Croatia. Brussels, Belgium: European Union Project. Retrieved from http://www.oijj.org/sites/default/files/baaf_croatia1.pdf

27 Justice for Children. (n.d.). UNICEF- Serbia. Retrieved from https://www.unicef.org/ serbia/activities_925.htm

28 See generally: Winterdyk, J. (ed.). (2015). Juvenile Justice: International perspectives, models, and trends. Boca Raton, FL.: CRC Press

29 See: Extrajudicial Measures. (2015). Ottawa: Department of Justice. Retrieved from http://www.justice.gc.ca/eng/cj-jp/yj-jj/tools-outils/sheets-feuillets/measu-mesur.html 


\section{Brief history and rationale for youth/peer courts}

Although the legacy of the youth justice movement dates to 1950's in the American State of Maine, where a judge wrote about such a concept in a local newspaper, there is no formal record of what transpired after the event. ${ }^{30}$ Furthermore, it has never been determined if such a program was implemented. Nevertheless, in the 1970s and coinciding with major juvenile justice reforms and support for diversion programs for young offenders, a couple of mostly northern States implemented what are now known as youth/teen/student/peer court and peer jury diversion programs (hereafter referred to as peer court). It is important to note that peer courts are not a formal court or a specialized court, they are diversion programs. During the 1970's and 80's most of these 20 or so peer court diversion programs did not expand to neighboring communities, as a result of social and political changes, and reforms throughout the country, as concerns over high rates of juvenile crime, a growing concern over the rise of youth gangs, along with a gradual shift towards the use of more punitive measures such as incarceration. ${ }^{31}$

Nevertheless, by the early 1990's, the peer court concept began to take hold in local communities and evolve thanks in large part to the efforts of those who believed that young offenders, especially those first-time offenders and/or youth having committed minor offenses, should be diverted from the formal process of youth justice and juvenile justice systems, but still be held accountable for their actions. It was not until 1997, when the United States Department of Justice launched the first federal effort within its Office of Juvenile Justice and Delinquency and Prevention (OJJDP) to actively undertake a wide range of federally funded projects, utilizing millions of dollars in tax payer funding for the specific purpose to proliferate these peer court diversion programs throughout the United States of America. This federal funding continued for a decade, until OJJDP suffered major reductions in federal funding, combined with the elimination of its research and training division. However, by 2008, the number of peer court diversion programs in the USA had passed an impressive 1,200+ communities now operating one of these peer court diversion programs. It is interesting and important to note, the Federal Government in the United States of America has never funded any local peer court diversion program - their rapid local expansion has been a textbook example of a grassroots social justice movement in America, which has now spread to Germany, Japan, England, South Korea, Trinidad, Tobago, and Egypt, in addition

30 Peterson, S. B. (2009). "Made in America: The Global Youth Justice Movement”. Reclaiming Children and Youth International Journal. Volume 18, Number 2, Pages 48-52.

31 See, generally: McCord, J., et al. (2000). Juvenile crime - Juvenile justice. Washington, D.C.: National Academy Press. Retrieved from https://www.nap.edu/read/9747/chapter/1

[8] NBP • Žurnal za kriminalistiku i pravo 
to other countries with operational peer courts, and still more countries in various stages of establishing a demonstration peer court.

In part, driven by the continued interest in these peer court diversion programs, both in the United States and abroad, a new private philanthropic-based company called Global Youth Justice, LLC (i.e. Limited Liability Company) was created in 2009, with the specific purpose to continue the expansion of peer court diversion programs in America and around the globe. Between 2009 and 2017, Global Youth Justice had trained more than 2,000+ adults at sixteen (16) training institutes, dozens of technical assistance projects, and a wide range of other programs and services in support of implanting and enhancing peer court diversion programs. The success of Global Youth Justice, LLC led to it being transitioned to an International Nonprofit Corporation called Global Youth Justice, Inc. with a board of directors and a newly expanded plan for more programs and services aimed at the continued expansion of peer courts around the globe.

\section{Overview 'peer courts'}

Over the past two decades, hundreds of communities have determined that they needed a youth court because youth courts offer a positive alternative to traditional juvenile justice and school disciplinary procedures. Additionally, youth courts:

- Serve as a prevention and early intervention program;

- Hold juvenile offenders accountable for their actions;

- Provide another option on the continuum of services available to youth;

- Promote restorative justice principles;

- Educate youth about the legal system;

- Offer an opportunity for young people to connect positively with adults and youth from their community; and,

- Encourage youth to take ownership in their own health and well-being and that of their communities.

Peer court diversion programs address the problem of anti-social, delinquent, and criminal behavior engaged in by youth typically between the ages of 10-18, with the goal of reducing the incidence and preventing the escalation of such behavior. To the extent that peer judgments are influential, a sentence imposed by a jury of peers will shape positive behavior. Sentencing in peer courts is designed to hold youth accountable according the idea that peer pressure exerts a powerful influence over adolescent behavior. If peer pressure 
leads juveniles into law breaking, it can be redirected to become some force leading juveniles into law-abiding behavior. Service on another jury will enable youth who have committed a crime, offense and/or violation to participate in the juvenile justice system, rather than being the object of that system, thereby causing and reinforcing positive behavior. The diversion of cases to peer courts will reduce the caseload of the courts and the probation office, resulting in saving time and resources, and thereby allow valuable resources to be directed to the more serious crimes and juvenile offenders.

The Youth Court Diversion Program envisions the deterrence of negative juvenile behavior by redirecting youth to behave in a pro-social manner and therefore become an asset to our community. Through the Youth Court model, it strives to promote feelings of self-esteem and desire for self-improvement, and foster a healthy attitude toward rules and authority. Operationalized properly, the youth court model provides guidance, rehabilitative placements, mentoring and close supervision of juvenile offenders and, in turn, is designed to promote youth to become positive contributing citizens of their community.

Peer court diversion programs also benefit youth volunteers, to include former youthful offenders who appeared in peer court, who participate in Youth Court as members and volunteer jurors, by increasing their knowledge of the criminal and juvenile justice system and facilitating development of important skills relating to the analysis of information, determination of its relevance and importance, and articulating and advocating positions. Youth volunteers typically serve in the roles of a judge, prosecutor, defender, clerk/bailiff, and jury foreperson, and will be required to complete successfully a multi-week law-related educational program. Volunteer youth jurors often consist of any youth who wishes to participate. Typically, Youth Court members consist of young people of high school age (i.e. 15-18 years of age) who have completed a multi-week course of law-related instruction. ${ }^{32}$

If introduced (perhaps pilot tested) in the Balkans, this system would help promote awareness of the rule of law and the functioning of the legal system among all young people. It would potentially reach the entire spectrum of young people, from youth who have committed an offense, to youth who wish to invest only a small amount of their time as jurors, to youth who are willing to invest substantial time, effort, study, and energy in the program.

32 Areas of instruction include an overview of the criminal justice system from arrest through appeal, the organization of youth court, including jurisdiction operation procedure and rules, the penal law, the consequences of crime to victims, the courts, the police, the probation office, and the community at large, the role of sentencing in rehabilitation of offenders, the range and effectiveness of rehabilitative actions and programs that are available, and sentencing issues, including aggravating and mitigating circumstances, and the nature and type of evidence that is admissible and probative in sentencing. 
In addition to peer court being called different names, the peer courts have been established and administered in a variety of ways. Yet, most of the programs are used as an alternative sentencing option for (mostly) first time offenders who have committed non-serious/non-violent crimes. The volunteer youth and youthful offenders are both usually between the ages of 10 to 18 , and in many of the programs the parent or guardian of the defendant must agree to the youth offenders' participation in the peer court. In addition, and like the more established diversion type programs in Canada and several other western countries, generally the youth has admitted to his or her wrongdoing (i.e. guilt) and then when provided with the option, voluntarily participates in a peer court rather than following the traditional and formal trajectory of the youth justice process.

Furthermore, in addition to representing an alternative to conventional youth justice measures and promoting civic engagement, the youth court model differs in that they rely on other young persons to pass on judicially the offender's sanction. Typically, the sanctions range from a combination of community service, conflict resolution training, restitution, jury duty, and/ or educational workshops. Furthermore, depending on the model used, the youth serving as court officials may serve as jurors, prosecuting attorneys, defense council, clerks, and even as judges. Overall, the peer court dispositions place an emphasis on rehabilitative and restorative goals - typically including: the performance of community service; victim restitution; and service on a future youth court jury. In addition, the specific areas in which benefits are anticipated for juvenile offenders in the Balkan region include the areas of knowledge, attitude, skill, satisfaction, and economy. They are described in greater detail below.

1) KNOWLEDGE. Knowledge is generally defined as: the aggregate of facts, information, and principles that an individual has acquired through learning and experience. The Youth Court programs are constructed to focus directly on identifiable areas in need of increased law-related education, including areas of substantive criminal law, criminal procedure, and rehabilitation.

2) ATTITUDE. An attitude is generally defined as: a state of readiness, a tendency to act or react in a certain manner when confronted with certain stimulation. Youth Courts are designed to promote positive attitudes toward and respect for the law and the criminal justice system.

3) SKILL. Skill is generally defined as: the ability required performing a specific task. Youth Courts are intended to promote the development of skills in the analysis of information, determination of its relevance and importance, articulation of facts, inference and conclusions, advocacy and decision making. 
4) SATISFACTION. In a general context, satisfaction refers to an individual's positive evaluations or assessments of a given situation. Youth Courts are created to achieve among participants a sense of satisfaction with the criminal justice system process through their direct participation in cases and influence over outcomes.

5) ECONOMY. Economy can be characterized as the prudent and efficient use of resources and material. Accordingly, the goal of Youth Courts' is to utilize volunteer and community resources to address problems of inappropriate youth behavior before that behavior escalates to the point of imposing costs on the traditional criminal justice system.

What is further unique about the model, and which could work well in the Balkan region context, is that peer courts are established within and by local communities. Hence, they are adaptable to the social, cultural, ethnic, and other possible key factors that can accommodate different community needs. Although there are currently over $1,700+$ of these peer courts, it is unique that it is largely left up to the community to determine what type of entity will serve as the administering agency to operate the peer court diversion programs. Police, probation, juvenile court, youth bureaus, district attorney's offices, public defender offices, schools, youth serving agencies, community service organizations, and a wide range of nonprofit organizations operate peer courts. In almost all cases, it is necessary for the elected and appointed officials to approve these peer court programs to be established, and operate within approved guidelines by the stakeholders.

An integral component for the success of a peer court is contingent upon local support and involvement of community members from diverse sectors. It is essential to recognize, for example, that the peer court model cannot operate without the coordinated collaboration of local agencies and community efforts. In so doing this also ensures the sustainability of the program regardless of economic and/or political agendas. Because the programmatic and operational design of peer court diversion programs require considerable volunteer involvement from both youth and adults, these peer courts are among the least expensive diversion programs to operate within a system of graduated sanctions, which also has allowed these peer court programs to further expand and remain operational, even when communities have deficits and/or budgetary problems. $^{33}$

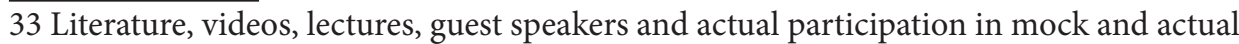
cases are the primary tools used to provide knowledge to the prospective Youth Court members. Youth Court members in turn will provide instruction and guidance to volunteer jurors and offenders.
} 


\section{Peer court models}

As noted above, peer courts are characterized not only by different names but also by different operational models that can be helpful to describe them. More importantly, the flexibility of the model allows for adaptation and/or accommodation to different regions in the Balkans where some of the models might not be as practical to implement as others.

For discussion purposes, there are four main program models, which have dozens of programmatic, operational, and administrative practices, which again, give local communities considerable options to operate a peer court that works best for them. Almost all models require a youth to admit guilt, so therefore, the peer court is not a trial, but rather a sentencing hearing, where the youth present evidence relevant to sentencing. The four primary models include:

1) Adult Judge Model which relies on an adult judge (usually voluntary) to preside over the courtroom procedure and ensure legal protocols are properly followed. However, youth volunteers are typically between the ages of 14-18 and serve as defender, prosecutor, clerk/bailiff and jurors.

2) Youth Judge Model is like the Adult Judge Model except that a youth volunteer serves as a judge. In some program models, the youth judge has first served as a volunteer in peer court in the other roles for a period.

3) Peer Jury Model draws on the peer model, in that the model uses a panel of youth jurors who question the offender directly. Under this model there is no one defender, prosecutor, or judge. With this model, the judge is often an adult volunteer who has essential knowledge of the legal system and due process.

4) Tribunal Model parallels the adult system in that there is no peer jury. Instead, typically the youth serve as the judge, prosecutor and defender, and present cases to an adult judge who then determines the appropriate sanction.

Regardless of which model a community selects, most peer courts are situated either in a youth justice system (i.e. police, probation, and delinquency court), in a school, or within a community non-profit setting. Coincidentally, these three settings are almost equal in terms of peer courts being operated within these three settings. Typically, most peer court models hold hearings 2-3 times per month and the most common agencies operating or administering youth court programs are juvenile courts and private nonprofit organizations (29\% each). The next most common agencies are law enforcement agencies and juvenile probation departments (17\% each). Schools are the operating agencies for about 10 percent of youth courts while a variety of other agencies (e.g. city government, the administrative office of the court) 
are less commonly the operating agency. However, some communities hold peer court hearings weekly, once a month, and even twice a week. The remaining modes of delivery have covered the spectrum from local governments, the administrative office of the courts, and/or some other formal organization such as a bar association or district attorney office. Various American based studies have shown the successful completion rate of dispositions runs as high as $88 \%$ compared to only around $15 \%$ not reoffending after being referred to probation or some other conventional sanction for a subsequent offense. ${ }^{34}$

Irrespective of the peer court model, all models strive to attain a "constructive disposition" (i.e. accountability) for the defendant that is seen to have a restorative and/or rehabilitative component to it. Hence, the main sentencing outcomes involve some form of community service or participation in an educational type program. However, other options can and have been used. In more than $50 \%$ of all peer court diversion programs in the United States, peer court hearings are held in the evening in adult criminal justice courtrooms when they are not in use. About $30 \%$ of peer court hearings take place in school, with the remaining $20 \%$ being held in various locations such as a government building, youth bureau or law enforcement settings.

The Youth Court program/model is designed to operate year-round. Offenders who are involved in the youth court program are referred by the police department, county probation department, and the justice courts. Types of offenses committed are generally first time, misdemeanor and/or violations. In North America, typical cases referred to Youth Court are shoplifting, larcenies, criminal mischief, vandalism, harassment, unlawful possession of marijuana, etc. However, different jurisdictions may choose to explore different case scenarios based on case profiles and social-cultural-political will and capacity. Again, the choice of which cases in the region might best qualify for such a program is something that local policy-makers and experts could discussion and then decide upon.

All peer court models create a positive and educational alternative to the already overburdened Balkan states' youth justice systems. Yet, a typical and comparable response can be found in the comments by Margaret Waddell ${ }^{35}$ who wrote that the four best ways to address an overburdened judicial system (in Ontario, Canada) was to: 1) hire more clerks for the judges, 2) create an online reservation system for motion scheduling, 3) abolish automatic dismissals; and, 4) establish a province-wide online database of current court cases. And while she acknowledges that such changes would come with an additional price tag,

34 Peterson, S. B. (2009). "Made in America: The Global Youth Justice Movement". Reclaiming Children and Youth International Journal. Volume 18, Number 2, Pages 48-52. 35 Waddell, M.L. (2012). Four simple ways to make our courts more efficient. Retrieved from http://www.canadianlawyermag.com/4320/Four-simple-ways-to-make-our-courtsmore-efficient.html 
she suggests that the result would not only help to streamline the system but also make it more efficient. Yet, a fundamental detail overlooked in her argument is that the accused would still be subjected to the stigma of the court formal process and essentially conflates the underlying objective of the YCJA. Therefore, consideration of introducing the peer court model in the Balkan region could and pragmatically should help to streamline its juvenile justice system. Hence, provided there is social and political will, the proposed (and proven) peer court model would appear to offer a unique, cost-effective, and positive alternative to the handling of most minor offences committed by young offenders. The model would appear most practical in the rural and outlying areas where formal juvenile mechanisms are limited and/or not working efficiently or effectively.

A final argument that could be made for the introduction of youth/peer courts in the Balkan region is that an overarching characteristic of the model is that it also embraces elements of crime prevention. Using crime prevention measures, as have been well documented over the years, ${ }^{36}$ is a far more effective and efficient means of addressing crime than relying on reactive response mechanism. By involving young persons in various elements and stages of the peer court model, it provides a direct and indirect means by which to educate young persons about the risks and harm of engaging in delinquent behavior. Also, by involving community capacity, there is a greater likelihood that other young persons (especially youth who might be deemed 'at-risk' of offending) will become informed about the process and make informed decisions that do not involve at-risk behavior.

To consider such change in a system that is already bureaucratically burdened, one might want to reflect on the sage reminder of Robinson-Easley who concluded her book on saving the youth with the phrase: "never give up on a child". ${ }^{37}$ Because, after all, children (as we all know) constitute the most vulnerable sector of the society and are considered supremely important assets to the future of any nation, including that of any of the Balkan countries.

\section{Conclusion and potential for peer court models within the Balkan region}

This article began with the observation that juvenile delinquency is an enigma from which no country appears to be immune from. And while crime trends have gone up and gone down at various times in most regions of the

36 See generally: Winterdyk, J. (ed.). (2017). Crime prevention. Boca Raton, FL.: CRC Press

37 Robinson-Easley, C.A. (2012). Our children, our responsibilities: Saving the youth we are losing to gangs. New York, Peter Lang, p. 206. 
world, the fact remains that juvenile crime remains omnipresent - regardless of whether one lives in Canada, Serbia, Croatia, or any other Balkan country, let alone other regions in the world.

It was that despite the relative decline in young persons in the region that juvenile crime remains an issue (for some countries more than others), that the available resources (especially within the current structure of the juvenile justice system) are being stretched to, if not beyond their limits. Therefore, a system which has existed for centuries is proving not as capable to address the types of activities efficiently nor effectively that erode the stability, safety, and security of a country. Again, as discussed briefly, from a human rights and social justice perspective, it is important to explore other viable alternatives to conventional juvenile justice practices if not for the well-being of the Balkans but arguably and more importantly for the well-being of its youth who will one day become those who lead and shape the region and countries within the region.

Although the peer court model is not considered to represent a panacea for the plight of juvenile crime in the Balkans - let alone anywhere else in the world - but based on the evidence available in other jurisdictions, its rapid expansion, and its adaptability, the model offers a viable alternative to conventional response mechanisms that are currently used and relied upon in the region. Also, fortunately, through various local initiatives and studies, and part of the work undertaken at the MPPG there are (arguably) signs of opportunity to more the respective models and practices of juvenile justice in the region to allow for the program to be introduced and/or experimented with in a context that might 'best' reflect to social, political, and cultural values of each of the regions countries.

Should the idea be introduced/experimented in the region, the program would help to reduce the burden to the formal elements of the system and thereby optimize the use of alternative measures or alternative sanctions as readily as it could, or arguably should. Again, based on available (although limited in English) evidence in the Balkan region, the use of the peer court model would create considerable opportunity to establish additional community-based/alternative measure options that can be incorporated by the Balkan States juvenile justice legislation to help alleviate some of the burden on the formal juvenile justice system and build some community capacity which as Dandurand ${ }^{38}$ points out is essential to building/restoring social well-being within communities.

Therefore, aside from offering a viable alternative to existing extrajudicial programs within the Balkan states' juvenile justice system, the highly successful, and affordable peer court models would appear to offer their respective juvenile youth justice systems several instrumental and functional benefits. They include, among others:

38 Dandurand, Y. (2017). Preventing Violence against Children: The UN Model Strategies, In: J. Winterdyk, J. (ed.). Crime prevention. Boca Raton, FL.: CRC Press

[16] NBP • Žurnal za kriminalistiku i pravo 
- Civic engagement of both young offenders and youth in general.

- Foster youth and adult partnerships that are continual service and not just episodic.

- Various studies have shown them not only to be effective in reducing re-offending rates, but the programs are among the least expensive youth justice programs. For example, Peterson ${ }^{39}$ cites a study conducted by the prestigious George Washington University where they calculated the average annual cost of operating a youth court was around $\$ 55,000 \mathrm{US}$ per year. This clearly pales by comparison to the salary of one judge, let alone factoring in the costs of lawyers, bailiffs, clerks, etc.

- Since most of the youth involved in such programs are between the ages of 10-18, they are often still in need of guidance and a 'second chance'.

- The peer court model would align with a key objective of the CRC, that is, promoting rehabilitation and reintegration of the young offender back into society.

Evidence that the proposed program would attract the participants can be summed up in two words - "Peer Justice." Offenders participate because they can be judged by their peers rather than adults and be diverted from the traditional criminal justice system. They are also able to have their case handled in a swift, effective, and efficient manner.

Although this article did not address some of the pragmatic issues such as how to recruit and train both youth and adult volunteers, types of referral sources and the referral process, the implications of deferring young offenders into such programs, or how best to standardize the establishment of peer court models, the focus of this article was simply to introduce the concept, stimulate interest in the concept, and ideally generate an initiative to explore and pilot test the model within the Balkan context on a local level.

Finally, what has been proposed in this article is not revolutionary, but it does/may call for a degree of 'risk-taking'. However, with informed and evidence-based innovation, there is considerable potential for the Balkan states, or even various communities in the region to undertake pilot programs that could demonstrate the potential value of such an initiative. And along with the growing capacity of criminal justice and criminology scholars in the region they can work in consort to ensure proper monitoring and evaluation of such a model or program. In doing so, this could serve to create a potentially more effective juvenile justice system that is largely founded on rehabilitation and restorative concepts and which also helps to build community capacity, and further aligns with the CRC.

39 Peterson, S. B. (2009). "Made in America: The Global Youth Justice Movement". Reclaiming Children and Youth International Journal. Volume 18, Number 2, Pages 48-52. 


\section{References}

1. Balkan Barometer 2015 Public Opinion Survey. (2015). Regional Cooperation Council Secretariat (RCC) Sarajevo, Slovenia. Retrieved from http:// www.rcc.int/seeds/files/RCC_BalkanBarometer2015_PublicOpinion_ FIN_forWeb.pdf

2. Bezic, R. (2017). Juvenile delinquency in the Balkans. Cardiff, Wales: $17^{\text {th }}$ Annual European Society of Criminology conference.

3. Buric, A. (2011). Youth crime law stalls in Bosnia. Retrieved from http:// www.balkaninsight.com/en/blog/youth-crime-law-stalls-in-bosnia

4. Buric, A. (2011). Rehabilitating Hungary's young offenders. Retrieved from http://www.balkaninsight.com/en/blog/rehabilitating-hungary-s-young-offenders

5. Buric, A. (2011). Federation fails to curb rising Bosnian youth crime. Retrieved from http://www.balkaninsight.com/en/article/federation-fails-tocurb-rising-bosnian-youth-crime

6. Dandurand, Y. (2017). Preventing Violence against Children: The UN Model Strategies. In: J. Winterdyk, J. (ed.). Crime prevention. Boca Raton, FL.: CRC Press.

7. Dash, P.K. (2013). By 2017, India's slum population will rise to 104 million. The Times of India. Retrieved from https:/timesofindia.indiatimes. com/india/By-2017-Indias-slum-population-will-rise-to-104-million/ articleshow/21927474.cms

8. Derencinovic, D. \& Getos, A-M. (2009). Uvod u kriminologiju s osnovama kaznenog prava. Zagreb. Pravni fakultet Sveucilista u Zagrebu.

9. Extrajudicial Measures. (2015). Ottawa: Department of Justice. Retrieved from http://www.justice.gc.ca/eng/cj-jp/yj-jj/tools-outils/sheets-feuillets/ measu-mesur.html

10. Getos Kalac, A-M. \& Bezic, R. (2017). Criminology, crime and criminal justice. European J. of Criminology, 14(2): 242-266.

11. Ginio, E. (2016). The Ottoman culture of defeat. United Kingdom: C. Hurst \& Co.

12. Justice for Children. (n.d.). UNICEF- Serbia. Retrieved from https://www. unicef.org/serbia/activities_925.htm

13. Kilchling, M. (2016). "Violence in the Balkans in the focus of Balkan Criminology's current research activities". 3rd Annual Conference of the Max Planck Partner Group for Balkan Criminology "Violence in the Balkans". Faculty of Law, University of Bucharest/Romania.

[18] NBP • Žurnal za kriminalistiku i pravo 
14. Klarin, M. (2009). The Impact of the ICTY Trials on Public Opinion in the Former Yugoslavia. Journal of International Criminal Justice, 7(1): 89-96

15. Krastav, I. (2002). Democracy without choice. Journal of Democracy, 13(3): 39-53. Retrieved from http://commonweb.unifr.ch/artsdean/pub/ gestens/f/as/files/4760/25735_093221.pdf

16. McCord, J., et al. (2000). Juvenile crime - Juvenile justice. Washington, D.C.: National Academy Press. Retrieved from https://www.nap.edu/ $\mathrm{read} / 9747 /$ chapter/1

17. Marsavelski, A. (2012). Alternatives to custody for young offenders: National report on juvenile justice trends: Croatia. Brussels, Belgium: European Union Project. Retrieved from http://www.oijj.org/sites/default/files/baaf_ croatial.pdf

18. Miladinovic, Z. (2016). Youth court statistics in Canada, 2014/2015. Statistics Canada. Retrieved from http://www.statcan.gc.ca/pub/85002-x/2016001/article/14656-eng.htm

19. Oudshoorn. J. (2015). Trauma-informed youth justice in Canada. Toronto: CSPI.

20. Peterson, S. B. (2009). "Made in America: The Global Youth Justice Movement". Reclaiming Children and Youth International Journal. Volume 18, Number 2. Pages 48-52.

21. Peterson, S.B. (2017). Teen, peer youth court. Retrieved from http://www. globalyouthjustice.org/Training_and_Events.html

22. Robinson-Easley, C.A. (2012). Our children, our responsibilities: Saving the youth we are losing to gangs. New York, Peter Lang.

23. Sijerčić-Čolić, H. (n.d.). Juvenile justice as a key element of national human rights policy and restorative juvenile justice - recent trends in juvenile delinquency and juvenile justice in Bosnia and Herzegovina. Retrieved from https://www.unicef.org/tdad/5hajrijasijercic.pdf

24. Votja, F. (2015). Imprisonment in the Balkans: Some remarks on the life and long-term imprisonment in countries of former Yugoslavia. Balkan Criminology New. 1: 1-5.

25. Vujovic, S. (2015). International Self Report Delinquency Study (ISDR-3) in Bosnia and Herzegovina. Balkan Criminology New, 1: 8-9.

26. Waddell, M.L. (2012). Four simple ways to make our courts more efficient. Retrieved from http://www.canadianlawyermag.com/4320/Four-simpleways-to-make-our-courts-more-efficient.html

27. Waller, I. (2013). Smarter crime control. New York, NY: Rowman \& Littlefield 
28. Winterdyk, J. (ed.). (2015). Juvenile Justice: International perspectives, models, and trends. Boca Raton, FL.: CRC Press.

29. Winterdyk, J. \& Smandych, R. (eds.). (2016). Youth at risk and youth justice $\left(3^{\text {rd }}\right.$ ed.). Toronto, ON: Oxford University Press.

30. Winterdyk, J. (ed.). (2017). Crime prevention. Boca Raton, FL.: CRC Press.

31. Zivanovic, M. (2017). Balkan states face big population drops, UN warns. Balkan Insight. Retrieved from http://www.balkaninsight.com/en/article/ populations-plunging-in-most-balkans-countries-report-06-22-2017 


\section{KORIŠĆENJE KAPACITETA POZITIVNOG PRITISKA VRŠNJAKA KROZ GLOBALNI POKRET MLADIH ZA PRAVDU: „ZLATNA“ PRILIKA ZA BALKAN}

\section{Džon Vinterdik ${ }^{1}$}

Katedra za studije ekonomije, pravosuđa i politike Univerzitet Maunt Rojal, Kalgari, Alberta, Kanada

Sažetak: Kategorija maloletničke delinkvencije za većinu naroda, uključujući i uopšteno narode na Balkanu, jeste poput enigme još od uvođenja prvih zakona o maloletnicima u pravosuđe. U novije vreme maloletnička delinkvencija na Balkanu ne samo da je u porastu, već i ozbiljnost ovih dela pokazuje uzlazni trend i još više opterećuje već opterećeni sistem maloletničkog pravosuđa. Ovaj rad predstavlja jednu alternativu mogućnost u odnosu na formalni sistem maloletničkog pravosuđa, mogućnost koja je osmišljena da osnaži mlade, da podigne kapacitet zajednice i sposobnost oporavka mladih i koja je po prirodi reintegrativna i restorativna. Dat je pregled modela vršnjačkog suda koji je opisan u mogućem balkanskom kontekstu. Raspravlja se o različitim dokazima o relativnom uspehu ovog modela u ostalim regionima u svetu. $U$ zaključku rada dato je nekoliko zapažanja u pogledu pitanja zašto bi model vršnjačkog suda mogao/trebalo da se usvoji u zemljama Balkana uz nekoliko pragmatičnih i praktičnih razmatranja u pogledu primene i vođenja ovog modela.

Ključne reči: maloletnička delinkvencija, vršnjački sud, alternativne mere, odvraćanje, restorativna pravda

1Redovni profesor, jwinterdyk@mtroyal.ca 
